
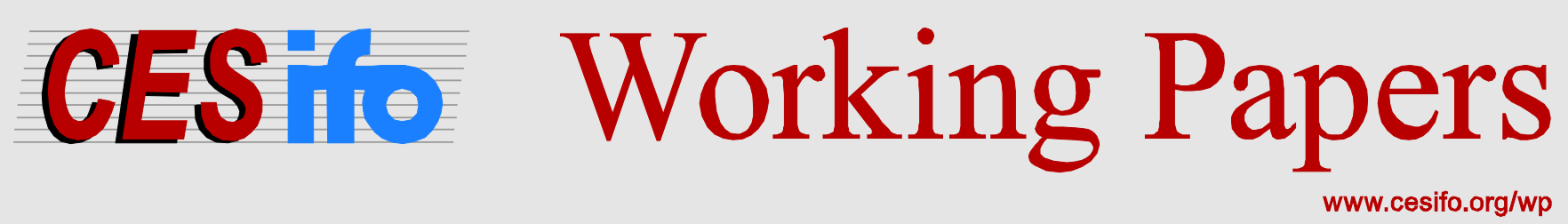

\title{
Economic Growth and Judicial Independence, a Dozen Years On: Cross-Country Evidence Using an Updated Set of Indicators
}

\author{
Stefan Voigt \\ Jerg Gutmann \\ Lars P. Feld
}

CESIFO WORKING PAPER NO. 5010

CATEgORY 2: Public CHOICE

OCTOBER 2014

An electronic version of the paper may be downloaded

- from the SSRN website:

- from the RePEc website:

- from the CESifo website:

wWw.SSRN.com

www.RePEc.org

www.CESifo-group.org/wp

\section{CESifo}




\title{
Economic Growth and Judicial Independence, a Dozen Years On: Cross-Country Evidence Using an Updated Set of Indicators
}

\begin{abstract}
Over 10 years ago, Feld and Voigt (2003) introduced the first indicator for objectively measuring the actual independence of the judiciary and demonstrated its utility in a large crosssection of countries. The indicator has been widely used, but also criticized. This paper presents more recent data on de jure and de facto judicial independence (JI) and strongly confirms previous results that de jure $\mathrm{JI}$ is not systematically related to economic growth, but de facto JI is highly significantly and robustly correlated with growth. In addition, we show that the effect of de facto JI depends on the institutional environment, but not on a country's initial per capita income.
\end{abstract}

JEL-Code: H110, K400, O400, P510.

Keywords: judicial independence, economic growth, rule of law, constitutional economics, governance, measuring institutions.

Stefan Voigt

Institute of Law \& Economics

University of Hamburg / Germany

stefan.voigt@uni-hamburg.de
Jerg Gutmann

Institute of Law \& Economics

University of Hamburg / Germany

jerg.gutmann@uni-hamburg.de

Lars $P$. Feld

Walter Eucken Institute

University of Freiburg / Germany

feld@walter-eucken-institut.de 


\section{Economic Growth and Judicial Independence, a Dozen Years On: Cross-Country Evidence Using an Updated Set of Indicators}

\section{$1 \quad$ Introduction}

Thriving market economies depend on strong states that secure private property rights. Yet, a state's strength can be its greatest weakness: if it is strong enough to secure private property rights, it may also be strong enough to violate them. This insight is not new; it was elegantly described as early as 1651 by Hobbes: "For he that hath strength enough to protect all, wants not sufficiency to oppresse all" (1651, Ch VI, n 3). Sometimes called the "dilemma of the strong state," the issue continues to be of interest, perhaps especially to scholars of political economy (see, e.g., Weingast 1993). Indeed, the protection of private citizens from the discretionary infringement of their rights by the state might be even more important for long-run economic development than the public enforcement of private contracts (Acemoglu and Johnson 2005). A simple promise to honor private property rights in the future will not be credible due to the state's time-inconsistent preferences and its ability to choose actions sequentially. The citizens know that after they have invested, the state has no incentive to keep its promise to protect private property rights. In such a setting, having an independent judiciary could make all actors better off: that is, if the judiciary is able to make the state keep its promises, the result will be additional and more productive (physical and human capital) investment, leading to faster economic growth, and also higher tax receipts for the state. The judiciary can reduce the time inconsistency of the government's preferences, in areas where it is unfeasible to delegate competences to independent bodies such as central banks.

In light of this seemingly win-win situation, one would expect that rational politicians had long since introduced judicial independence (JI). However, simply promising an independent judiciary is not sufficient to induce additional investment: if potential investors do not believe that the judiciary really is impartial, they will not change their investment behavior. It thus makes sense to distinguish between two kinds of JI: de jure and de facto. In short, de jure $\mathrm{JI}$ is what the law says (i.e., the law on the books); de facto JI is what the law does (i.e., the actual independence enjoyed by judges). The latter will be the result of their effective term lengths, the degree to which judgments have an impact on government behavior, and so forth. Furthermore, a judiciary that has effectively enjoyed independence has a reputation-enhancing effect on the government, making it even more costly to interfere with the judiciary's independence in the future. This allows for the simultaneous establishment of different equilibria with high and low levels of independence. Different levels of JI can not only be explained by path dependencies, but might also result from countries' reliance on alternative constitutional commitment mechanisms to JI, for example federalism.

Feld and Voigt (2003) introduced both a de jure and a de facto indicator of JI about a decade ago. As the first objective way to evaluate de facto JI across countries, the indicators met with 
great interest but also with some criticism (e.g., Rios-Figueroa and Staton 2012). This paper updates both indicators and then employs them to answer three questions. (1) Does JI have a significant impact on economic growth? For this purpose, we replicate the results of Feld and Voigt (2003) for a more recent time period and a larger country sample. (2) Are improvements in JI associated with higher growth rates? Here we can employ changes in our indicators between the two waves. (3) Given that the effect of JI also depends on other constitutional traits, can these traits serve as substitutes for or complements to JI?

Based on a sample of as many as 104 countries and analyzing GDP per capita growth between 1990 and 2008, we find that (1) de jure JI is virtually uncorrelated with economic growth, whereas de facto $\mathrm{JI}$ is highly significantly correlated with economic growth. The previous results by Feld and Voigt (2003) are thus confirmed. (2) Improvements in de facto JI are indeed significantly correlated with faster growth. (3) The effects of de facto JI on growth are not significantly different for low- and high-income countries. Furthermore, de facto JI and democratic institutions reinforce each other. The effect of de facto JI on growth is also reinforced by a high level of checks and balances. Moreover, although states with a federal system, two chambers of parliament, or greater freedom of the press appear to benefit less from an independent judiciary, these differences are not statistically significant.

The remainder of the paper is organized as follows. Section 2 briefly surveys the recent literature in several areas related to our research question, including attempts to produce independence measures (not necessarily restricted to the judiciary), and papers demonstrating the (economic) consequences of variation in the degree of separation of powers (of which JI is a crucial aspect). Section 3 recaps the central theoretical conjectures on which our empirical estimates build. This includes possible complementarities of JI with basic constitutional traits such as federalism or form of government. In Section 4, we present the two indicators. In Section 5, our indicator values are compared with those of other indicators. A number of bivariate correlations between the JI indicators and other important aspects of the separation of powers, such as federalism, bicameralism, and direct democracy are presented. Section 6 contains the regression model as well as the discussion of our results. Section 7 concludes the paper and contains suggestions for future research.

\section{A Brief Survey of the Recent Literature}

There have been various attempts to define JI. In their overview, McCubbins and Rodriguez (2006) distinguish between approaches that concentrate more on institutions and those concentrating more on the behavior of relevant actors. Rios-Figueroa and Staton (2012) make a distinction between approaches centering on the autonomy of the judges and those concentrating on their power. The construction of indicators of JI is, of course, heavily influenced by the basic definition of JI that is adopted.

Most indicators proposing to measure JI look at a number of institutional precautions that serve to insulate the judiciary from the other government branches. The various aspects of 
insulation are then coded and aggregated into a single indicator. The conceptual idea behind this approach is that the more insulated the judiciary is from the other government branches, the more independent it is from them. However, insulation is only likely to affect actual behavior to the degree that it is actually effective; in other words, promises of insulation are not the same as actual insulation. This is why Feld and Voigt (2003) introduced the very explicit distinction between measures of de jure and de facto JI, which is now accepted as standard in the literature. ${ }^{1}$

In the introduction to this paper, an independent judiciary is discussed as being a possible solution to the government's commitment problem. The judiciary is not the only device used to mitigate that problem, however, and other devices have some similarity with the judiciary. For example, one strand of literature is concerned with the role and effects of independent agencies, such as those dealing with competition, network industries, the environment, the fight against corruption, and monetary policy. A second strand inquires into the effects of the separation of powers as mandated on the constitutional level. We briefly summarize both literatures below.

Independent agencies have taken over an increasing number of tasks during the last several decades. Sometimes, these agencies are referred to as "non-majoritarian institutions" (Majone 2001) as their heads are usually appointed rather than elected by popular vote. It is conjectured that this trait gives them less incentive to cater to the possibly short-term wishes of the general electorate (something politicians are prone to do in their bids for election), thus making their commitments more credible. Therefore independent agencies have much in common with JI and we now briefly discuss some of the relevant literature on this topic.

There has been a long and intensive debate over whether central bank independence (CBI) is conducive to lower inflation. Arnone et al. (2006) survey many indicators of CBI; Klomp and de Haan (2010) subject the entire literature to a meta-regression analysis and find that the main result — high levels of CBI are correlated with lower inflation-holds regardless of the specific indicator used, the time period studied, and for both panel and cross-country regressions. It is conjectured that this is because central bankers, who are not subject to re-election pressure, are better able to carry out promises of tight monetary supply and can thus make more credible commitments than can politicians seeking re-election. Various approaches toward measuring CBI have been proposed (e.g., Cukierman 1992; Cukierman et al. 1992; Debelle and Fisher 1995; Grilli et al. 1991). This work finds that de jure CBI is a good predictor of monetary stability in OECD countries only, and that the turnover rate of central bank governors (a de facto proxy) is a much better predictor for less developed countries (for sur-

1 Although it is, at times, interpreted rather oddly, as in Rios-Figuero and Staton (2012), who equate de jure JI with the incentives to behave and de facto with actual behavior. This distinction between de jure and de facto, however, makes only sense if de jure institutions are actually implemented. Our hunch that this is often not the case is why we introduced a de facto-measure in the first place. 
veys, see Berger et al. 2001; Hayo and Hefeker 2002). Keefer and Stasavage (2003) add to this literature by showing that a higher number of political veto players increases the negative effect of formal CBI on inflation levels. Hayo and Voigt (2008) find that higher levels of de facto JI are likely to trigger higher levels of de facto $\mathrm{CBI}$ and that de facto JI thus indirectly contributes to lower inflation. Many aspects relevant to measuring de jure and de facto CBI are also useful for measuring the independence of the judiciary - and are, in fact, used in this paper.

There are a number of other areas in which independence and its measurement play a key role:

- Researchers inquiring into the effects of independent regulatory agencies (such as those regulating telecoms, energy, food safety, and the environment) also deal with the issue of how best to measure independence. The issues discussed by these scholars are very similar to those discussed with regard to JI. Hanretty and Koop $(2012,2013)$ not only criticize some of the approaches, but also provide a brief survey of the relevant literature.

- Van Aaken et al. (2010) introduce indicators for the de jure and the de facto independence of prosecutors. The conceptual ideas underlying these indicators are analogous to those underlying the indicators discussed here. Substantively, the paper asks whether countries with more independent prosecutors have lower levels of corruption and answers this question in the affirmative.

- Voigt (2009) provides an indicator for the independence, both de jure and de facto, of competition agencies and finds that there is not much divergence between the two types of JI. This is a noteworthy finding because in most cases where de jure and de facto independence of public agencies have been ascertained separately, their bivariate correlation is low. Higher levels of competition agency independence, both formally and actually, are positively correlated with higher levels of total factor productivity.

The constitutional economics literature concerned with the way separation of powers is organized at the constitutional level is closely related to the topic of this paper. Early research in this area focused on the effects of the form of government, that is, the effects of having either a presidential or a parliamentary system. Research into the economic effects of constitutions received a substantial boost from Persson and Tabellini (2003), who find that presidential systems are conducive to lower spending on welfare services and budget deficits. At the same time, they find no significant effect on total factor productivity. Studies following in the footsteps of Persson and Tabellini inquire into the effects of federalism (Feld et al. 2005; Voigt and Blume 2012; Baskaran and Feld 2013; Asatryan and Feld 2013) or of direct democracy (Feld and Savioz 1997; Blume et al. 2009). In the empirical section of this paper, we test whether the interaction between de facto JI and a number of these variables can explain differences in growth. Such interactions will play a role if JI and other constitutional traits exhibit a pronounced complementary or substitutive relationship. 


\section{Why Should Judicial Independence Be So Important?}

JI implies that judges can expect their decisions to be implemented regardless of whether they are in the (short-term) interest of other government branches upon which implementation depends. It further implies that judges do not have to fear negative consequences as a result of their decisions, such as, for example, being fired, experiencing a cut in pay, or becoming less influential.

There are three archetypical interaction situations in which JI is crucial.

(1) Conflict between citizens. If parties have entered voluntarily into a contract and one of them believes that the other is in violation of the contract, impartial dispute resolution is necessary. As long as both sides expect the judiciary to be impartial, they can save on transaction costs. Lower transaction costs will lead to a greater number of welfareenhancing transactions.

(2) Conflict between the government and citizens. Citizens need an organization that can adjudicate who is right, that is, who has acted according to the law. The judiciary not only will have to ascertain the constitutionality of newly passed legislation, but will also have to check whether the representatives of the state have followed procedures designed to safeguard the rule of law. If the judiciary is not independent from the executive and the legislature, citizens will not trust in the rule of law.

(3) Conflict between government branches. In the absence of an impartial arbiter, conflicts between government branches are most likely to develop into power games. An independent judiciary can keep them within the rules laid out in the constitution.

Among the many functions of government, reduction of uncertainty is of paramount importance. However, the law will reduce uncertainty only if the citizens can expect the letter of the law to be followed. An independent judiciary thus could also be employed as a device for turning promises - for example, protection of private property rights - into credible commitments (Voigt and Gutmann 2013). If the judiciary performs this function, citizens will develop a longer time horizon, which will lead to more investment in physical capital and a higher degree of specialization. Hence, JI should be conducive to economic growth.

\section{$\underline{\text { Potentially Influential Constitutional Co-Variates }}$}

Research in constitutional political economy shows that constitutions can have important effects on a number of economic variables, including growth (for an overview, see Voigt 2011). Given that these constitutional traits are likely exogenous and not a function of JI, four possible relationships with JI are conceivable: (1) they might be neutral, that is, the one does not affect the relationship of the other with the dependent variable; (2) they might be complementary, that is, higher levels of JI will reinforce the effect of the respective constitutional trait or vice versa; (3) they might be substitutive, that is, one of the institutions will suffice to elicit 
the effect; or (4) they might be contradictory, that is, the presence of one keeps the other from functioning properly.

JI can be thought of as an aspect of the separation of powers as it defines the degree to which judges can make decisions without interference from other branches of the government. Separation of powers is one way of increasing a state's commitment capacity. Consequently, it seems advisable to analyze constitutional rules that directly impact the separation of powers. In constitutional political economy, the form of government, federalism, and bicameralism are found to play a central role, which is why we analyze the effect on economic growth each of them has in combination with JI.

Many scholars (e.g., Persson et al. 1997) argue that presidential systems imply a higher degree of separation of powers than do parliamentary systems. In presidential systems, the executive does not depend on the consent of the legislature for its survival, thus making it more independent. It can be argued that a stronger separation of powers is connected with a higher commitment capacity because important decisions need to be agreed to by more actors (see, e.g., Tsebelis 2002). If a higher commitment capacity is conducive to economic growth, then presidential systems should grow faster than parliamentary ones. This argument appears to be supported by the U.S. experience. It has also been observed that presidents often claim to be the only politicians representing the entire nation and that they are more likely than prime ministers to simply ignore the legislature. In such a situation, an independent judiciary could help monitor the behavior of presidents. Given that less of such monitoring is needed in parliamentary systems, an independent judiciary should display stronger effects in presidential systems.

Federalism is also strongly linked to the separation of powers. Yet, the higher number of veto players implied by federalism (as compared to a unitary state structure) also increases the potential for conflict among them. In this section, we conjectured that a judiciary independent from the other two branches of government might be beneficial if it is able to avert or at least settle conflicts between these veto players. We thus conjecture that JI should be particularly beneficial in the presence of a federal constitutional structure.

Bicameralism is one more aspect of the separation of powers. It is positively correlated with federalism as federally structured states need a chamber representing the states making up the federation. However, there are also many states with a unitary constitutional structure that have two legislative chambers. Our conjecture regarding the effect of JI in the presence of bicameralism is analogous to that regarding federalism: as the number of veto players in bicameral systems is higher compared to that of unilateral ones, there is more need for an independent actor able to act as arbiter. We hence expect JI to have a stronger effect in bicameral systems. 


\section{$4 \quad$ A Description of Our Two Indicators}

\subsection{Introductory Remarks}

The indicators presented in this section were first introduced in Feld and Voigt (2003). Although we agree that the exact universe of components that should be included in the indicator is open to debate, we leave the indicator completely unchanged to ensure comparability with the previous study. The only change is that the data are more recent and cover more countries. Some criticized the way we aggregate the data (for lack of a convincing theory, we add them up without weights). For example, Ginsburg and Melton (2012) suggest that some components should be multiplied. Again, we retain the original procedures for coding and indicator construction. However, the raw data are available upon request to other researchers interested in constructing their own indicators.

The creation of our indicator was based on a few guiding principles. First, in many countries, the judiciary is made up of thousands of decision-makers and complexity needs to be radically reduced to produce a single number. Since all court systems are organized hierarchically, with higher courts able to overrule lower courts, the independence of the highest court is crucial for the overall independence of the judiciary. Also, it is costly for a government to exercise control over numerous small courts throughout a country. Putting pressure on the highest courts is more feasible and likely cost effective. Therefore, we focus only on a country's highest court, regardless of whether it deals exclusively with constitutional issues (e.g., the German Constitutional Court) or whether it is the Supreme Court for all areas of law (e.g., the U.S. Supreme Court). Second, we are interested in an objective indicator based on verifiable facts rather than on subjective perceptions so that, in principle, anybody interested in recalculating our indicator should arrive at identical values.

\subsection{A De Jure Indicator for Measuring Judicial Independence}

Our first measure is based solely on the legal foundations of judicial independence as set out in official documents. ${ }^{2}$ We draw on 23 characteristics grouped into 12 variables in order to assess formal JI. Each of the 12 variables can take on values between 0 and 1, where greater values indicate a higher level of JI. A country with a maximum degree of JI thus would score 12. Unfortunately, we were not able to obtain data on all 12 variables for some countries. We therefore use the mean of those variables for which data are available. ${ }^{3}$ The 12 variables and the reasoning used for coding them are as follows:

(1 and 2) The independence of judges presupposes the stability of a set of institutional arrangements within which they operate. Formally, the stability of a court's powers and

2. The questionnaire on which the two indicators are based is available in the online appendix.

3. This means that equal weight is attached to all variables, as there is as yet no theory on which to base a quantification of their importance. One could also attach weights ex post, for example, by using factor analysis, such that the explanatory fit is maximized. Yet, in the absence of any appropriate theory, any weighting is more or less arbitrary. 
procedures depends on how difficult it is to change them. If they are specified in the constitution itself, we expect a greater degree of independence than in cases where these arrangements are fixed by ordinary law. This only holds, however, if it is more difficult to change the constitution than to pass ordinary legislation. We therefore asked (1) whether the highest court is anchored in the constitution and (2) how difficult it is to amend the constitution.

(3) The procedure for appointing judges may have a notable effect on the court's independence. As one of the court's chief purposes is to protect citizens from illegitimate use of power by the authorities as well as to settle disputes between the branches of government, it ought to be as independent as possible from the other branches. We hypothesize that the most independent procedure for judicial appointment is by professionals (other judges or jurists). The least independent method is appointment by one powerful politician (e.g., the prime minister or the minister of justice).$^{4}$

(4/6) Judicial tenure will be crucial for the independence of the judiciary. We assume that judges are most independent if they are appointed for life or up to a mandatory retirement age and cannot be removed from office, save by legal procedure.

(5) Judges are less independent if their term is renewable because then they have an incentive to please those who can reappoint them.

(7) Further, if members of one of the other government branches have discretion in determining the judges' salaries, it could create an incentive to take the preferences of these members into account. In contrast, general rules that salaries cannot be reduced increase the independence of the judiciary.

(8) Additionally, judges should be paid adequately relative to other positions available to those with their qualifications, such as practicing lawyers or law professors.

(9) Another component of JI is the accessibility of the court and its ability to initiate proceedings. More precisely, accessibility may not be part of JI sui generis, but a precondition for its becoming effective. For example, a court that is accessible only by a quorum of parliamentarians will be less effective in constraining government than a court that is accessible by every citizen.

(10) If the allocation of cases to the various members of the court is at the discretion of the chief justice, his or her influence will be substantially greater than that of the other judg-

4 The number of different ways highest court judges are nominated and appointed is surprisingly high. For example, in Greece, some judges are chosen via a draw from a pool comprised of all Greek law professors meeting certain criteria. Hanssen (2004) lists five different procedures used by U.S. states. Padovano and Fiorina (2012) note that a "multi-tier appointment", that is, one in which a specified proportion of all judges is appointed by a specific group (e.g., the upper house), may not only create an allegiance to the appointing group but also foster solidarity with other judges appointed by the same tier, which could lead to the emergence of well-defined factions on the court. 
es. It follows that in such an institutional environment, it could be worth trying to influence just the chief justice. We expect JI to be larger if there is a general rule according to which cases are allocated to members of the court.

(11) The authority given to the highest court does not bear directly on its independence. Yet, the court needs to have a certain level of authority in order to keep in check the behavior of the other government branches. If the constitution is interpreted as the most basic formal layer of rules for restraining (and enabling) government, then constitutional review, that is, the authority to decide whether legislation is in conformity with the constitution, is crucial. ${ }^{5}$

(12) If courts are required to publish their decisions, their reasoning can become subject to public debate, which will make it more difficult for other government branches to exert influence on the courts' decisions. Making public dissenting opinions will further increase transparency.

\subsection{A De Facto Measure for Judicial Independence}

We now turn to the issue of measuring actually implemented JI. As with the de jure indicator, no single proxy adequately reflects all relevant aspects of de facto JI; indeed, as many as eight variables are used. Again, each of the eight variables can take on values between 0 and 1 where greater values indicate a higher degree of JI.

The de jure indicator is based on legislation. Even if the constitution or ordinary law is changed frequently, exact values could be calculated at every single point in time. This does not hold for de facto JI. For example, the actual term length of highest court judges cannot be calculated immediately after a new constitution has been passed, but only after a longer period during which the legal rules have been in place. We therefore base the de facto indicator on events observed during the period between 1970 and 2010. This implies that the indicator is very sticky. We chose this approach because we think that the past matters for how JI is evaluated by citizens and other potential investors. That is, a government—or, more broadly, a regime — cannot attain a reputation as law abiding or JI respecting overnight. Below is a list of our eight variables and the reasoning used for their coding:

(1-3)A crucial aspect of de facto JI will be the effective average term length of the members of the highest court. For coding, we simply multiply the effective average term length in years by 0.05 .6 In other words, a country receives the highest possible score of 1 if the average term length is 20 years or more. If the actual term length and the one to be ex-

5 Logically, it is, of course, possible to separate judicial review from JI. We take judicial review into account in our measure of JI because it increases the formal power of the judiciary vis-à-vis the legislature.

6. This variable is closely reminiscent of the turnover rate (TOR) calculated for central bank governors and used as a proxy for their de facto independence. As noted in discussions regarding TOR, very long tenure can also indicate judges' compliancy with government. 
pected based on the law on the books deviate, the country is coded 0 in a second variable. Removing a judge before the end of his or her term can be a serious breach of JI. If such has occurred at least once, the country is coded 0 for our third variable.

(4) By changing the number of judges, a government can manipulate the court majority in its favor. This is what U.S. President Roosevelt intended with his plan to "pack" the Supreme Court. A change in the number of judges is interpreted as detrimental to JI.

(5 and 6) The importance of an adequate income was discussed above in regard to the de jure indicator. With regard to the de facto situation, we are interested in whether the income of judges has at least remained constant in real terms. However, the quality of court output not only depends on the income level of judges, but also on the number of clerks, the size of the library, the availability of modern computer equipment, and the like. We take this aspect into account by asking for the development of the court's budget.

(7) Any change in the legal framework of the highest court may raise concerns about the durability of these rules and is hence interpreted as an indication of low de facto JI.

(8) The de facto degree of JI is low if implementation of the highest court's decisions depends on action by some other branch of government. The more frequently court decisions have not been enforced, the lower the $\mathrm{JI}^{7}$

The de jure indicator is available for 124 countries. Collecting data on de facto JI is more difficult. To ensure a minimum amount of accuracy, countries are included only if at least three variables for de facto independence are available. As a result, only 118 countries are coded. ${ }^{8}$

The underlying data come from country experts who answered a questionnaire. They were not asked to make subjective evaluations of the situation in the country, but were asked to provide information on the legal structure of the judiciary and objective developments. Among the experts were supreme court judges, law professors, lawyers, and activists from organizations such as Transparency International. For most countries we received far more than one questionnaire, which enables us to double-check the answers and get back to the experts in case of ambiguity.

\section{$5 \quad$ Taking Stock}

\subsection{A First Look at the Two Indicators}

The new country scores (see Appendix 1), like the ones of 10 years ago (Feld and Voigt 2003), contain some surprises. Results deviating from our expectations could be interpreted as

7 This variable is somewhat subjective in that it presupposes an evaluation of whether or not the other branches cooperate with the court.

8 Countries for which the de facto index is not derived have a somewhat lower initial income and lower levels of education, but the difference is not statistically significant. 
red flags regarding the reliability of our indicators. And, indeed, in their discussion of various indicators purporting to measure JI, Rios-Figueroa and Staton (2012) find that our de jure indicator is not very reliable; however, the authors evaluate the reliability of the de facto indicator as high.

Remember, however that our central hypothesis states that only de facto JI will be crucial for economic growth. It is hence reassuring that others attribute a high reliability to our de facto indicator. Second, it is worth reiterating that de jure JI reflects mere promises by the government. It is not surprising that some of the countries that promise much are not necessarily among those in which de facto JI flourishes. In addition, it seems intuitive that younger countries that created the relevant constitutional rules fairly recently will have better scores than older countries, if the various components of JI have become part of the orthodoxy only recently.

Moreover, the credibility of our indicators is supported by certain concrete findings. First, the bivariate correlations between the old and the new indicators are both significant at the 1 percent level $\left(r_{d j}=0.47, r_{d f}=0.35\right)$. Second, Hayo and Voigt (2012) code about two dozen aspects of JI as safeguarded in countries' constitutions. Their data allow for measuring changes in JI between 1990 and 2005. Interestingly, changes in their indicators are not only significantly correlated with changes in our de jure indicator, but also in our de facto indicator $(\mathrm{r}=$ 0.28 and $\mathrm{r}=0.37$ respectively). Third, the differences between our de jure and de facto measures are highly correlated between the two waves $(r=0.34)$. Fourth, Law and Versteeg (2013) offer measures for constitutional underperformers as well as for overperformers: underperformers are those who deliver less than they promise (in terms of human rights), whereas overperformers are those who deliver more than they promise. The difference between our de jure and de facto measures is significantly correlated with their over-/underperformance variables.

Of course, our questionnaire respondents may not have been completely unbiased. For example, aside from the well-known social desirability bias, a loyal citizen could try to make his country look better than it really is or a political activist striving for improvement might try to make her country look worse than it really is. Furthermore, in principle, a judiciary that scrupulously follows the wishes of - say-the executive could score very high in the de factoindex: a dictator could nominate his family and friends as judges; as long as they conform to his wishes, he would not have an incentive to kick them out of office, reduce their salary or the court's budget, and so forth. However, the same argument could be made against any other objective independence indicator, such as the frequently used turnover rate of central bank governors.

\subsection{Bivariate Correlations with Other Variables}

Bivariate correlations (see Table 1) can provide insight into how JI is related to other important political institutions, which may, in turn, reveal whether these other institutions are 
used as complements to or substitutes for JI. For example, federalism is one approach to making politics more transparent and politicians more directly accountable to their constituents. Looking at Table 1 shows that countries with more checks and balances tend to have a higher de jure index. Autocracies promise less and parliamentary democracies promise more JI than other countries. Surprisingly, no constitutional trait is significantly related to the level of de facto JI.

Table 1: Correlations Between JI and Constitutional Design Features $(\mathrm{N}=114)$.

\begin{tabular}{lccccc}
\hline & DJ-JI & DF-JI & Checks & Feder & Bicam \\
\hline De jure JI & 1.00 & & & & \\
& & & & & \\
De facto JI & -0.01 & 1.00 & & & \\
& {$[0.94]$} & & & & \\
Checks & $\mathbf{0 . 3 1}$ & 0.07 & 1.00 & & \\
& {$[0.00]$} & {$[0.45]$} & & & \\
Federalism & 0.12 & -0.02 & $\mathbf{0 . 3 3} *$ & 1.00 & \\
& {$[0.20]$} & {$[0.83]$} & {$[0.00]$} & & \\
Bicameralism & 0.08 & -0.02 & 0.15 & $\mathbf{0 . 4 3}$ & 1.00 \\
& {$[0.39]$} & {$[0.80]$} & {$[0.12]$} & {$[0.00]$} & \\
Autocracy & $\mathbf{- 0 . 3 7 *}$ & -0.05 & $\mathbf{- 0 . 4 0 *}$ & -0.03 & 0.13 \\
& {$[0.00]$} & {$[0.58]$} & {$[0.00]$} & {$[0.77]$} & {$[0.16]$} \\
Presidential Democracy & 0.04 & -0.10 & 0.11 & 0.07 & -0.00 \\
& {$[0.67]$} & {$[0.31]$} & {$[0.24]$} & {$[0.47]$} & {$[1.00]$} \\
Semi-Presidential Democracy & 0.10 & 0.08 & 0.02 & -0.14 & $\mathbf{- 0 . 2 0 *}$ \\
& {$[0.31]$} & {$[0.41]$} & {$[0.86]$} & {$[0.13]$} & {$[0.03]$} \\
Parliamentary Democracy & $\mathbf{0 . 2 7} *$ & 0.08 & $\mathbf{0 . 3 0}$ & 0.09 & 0.04 \\
& {$[0.00]$} & {$[0.38]$} & {$[0.00]$} & {$[0.35]$} & {$[0.67]$} \\
\hline
\end{tabular}

Note: Pearson correlation coefficients, $\mathrm{p}$-values in brackets, *: $\mathrm{p}<0.05$.

\section{Estimation Approach and Data Description}

To test our hypotheses regarding the relationship between JI and a country's economic growth, we rely on a standard growth regression. Our empirical approach was chosen to ensure comparability of its results with those of Feld and Voigt (2003). We estimate the following equation:

$$
\Delta \mathrm{Y}_{\mathrm{i}}=\alpha^{*} \mathrm{M}_{\mathrm{i}}+\beta^{*} \mathrm{JI}_{\mathrm{i}}+\gamma^{*} \mathrm{Z}_{\mathrm{i}}+\varepsilon_{\mathrm{i}}
$$

where $\Delta \mathrm{Y}_{\mathrm{i}}$ is the average real GDP per capita growth rate of country $i$ between the years 1990 and $2008, \mathrm{M}_{\mathrm{i}}$ is a vector of standard explanatory variables, $\mathrm{JI}_{\mathrm{i}}$ is a vector of de jure and de facto $\mathrm{JI}, \mathrm{Z}_{\mathrm{i}}$ is a vector of additional explanatory variables introduced to prevent omitted variable bias, and $\varepsilon_{\mathrm{i}}$ is the error term.

Consistent with standard growth theory, the vector $\mathrm{M}_{\mathrm{i}}$ consists of three variables: "initial" real GDP per capita in 1990 ("initial income"), private and public investment in percent of GDP averaged over the period 1990 to 2008 ("investment"), and the percentage of secondary school attainment in the total population aged 15 and over in 1990 ("education"). The last is 
from the Barro and Lee (2013) dataset; the other two are from the Penn World Table 8.0 (Feenstra et al. 2013). GDP data are expenditure based and PPP adjusted at constant prices.

$<<$ Table 2 about here $>>$

The vector $\mathrm{Z}_{\mathrm{i}}$ is made up of four indicators. Average government consumption in percent of GDP between 1990 and 2008 ("government size") and average population growth ("population growth") are both from Feenstra et al. (2013). We also control for average trade openness measured by the sum of exports and imports as a share in GDP ("trade openness"), which is derived from the PWT 7.1 dataset, and the average inflation rate ("inflation rate"), taken from the World Development Indicators. Feld and Voigt (2003) contained an additional dummy variable for transition countries (mostly in Central and Eastern Europe) in part because the period covered by that paper was 1980 to 1998 and thus included the transition years. Some of the countries covered did not even exist until after 1990 and thus the growth rates for the 1980s were, of necessity, crude estimates. To ensure comparability with the previous study, we also include a transition dummy ("transition country"), but do not expect it to be significantly different from zero. Table 2 summarizes all variables employed in our regression analysis.

The empirical strategy is straightforward. First, a baseline regression is estimated, to which we add the two JI indicators and a set of additional control variables. In a second step, we study the influence of differences in JI across time, that is, whether improvement in JI is related to higher economic growth. In a third step, we investigate whether other political institutions such as parliamentary democracy or federalism operate as substitutes for or complements to JI. Finally, we test the robustness of the results.

\section{$7 \quad$ Estimation Results}

The estimation results of the baseline specification are presented in Table 3. In the basic growth model without JI, all coefficients have the expected sign. However, neither education nor the transition dummy is statistically significant. The insignificant transition dummy seems to indicate that these countries have become "normal" in the sense that they do not exhibit systematically different growth rates after controlling for a set of variables prescribed by standard growth theory. Residual plots and Cook's D identify a set of influential observations. Thus, the results reported in Table 3 are based on regressions that include country dummies for the Democratic Republic of Congo, China, and Trinidad \& Tobago-except where a robust estimator is employed. Further regression diagnostics indicate no problems with heteroscedasticity, model specification, or multicollinearity.

$<<$ Table 3 about here $>>$

The inclusion of both de jure and de facto JI reveals that de jure JI has a negative coefficient but is not significant. The picture changes radically, however, with regard to de facto JI, the effect of which is statistically significant at the 5 percent level. The coefficient indicates that a 
country that switches from a completely dependent judiciary to a completely independent one would be expected to grow 1.3 percentage points faster than a country that remained at the original level of de facto JI in an average year. Compared to the results of Feld and Voigt (2003), the coefficient is smaller in size, but estimated with more precision. An alternative coefficient estimate from a robust high breakdown estimation technique by Yohai (1987) indicates a 1.7 percentage point increase in the average growth rate. If these results are robust and causal, they imply that de facto JI plays a very important role in explaining differences in growth rates. ${ }^{9}$ We check the robustness of our results by including additional covariates: government consumption, trade openness, and the inflation rate, as well as population growth. Only the inflation rate is significant and has the expected negative sign. The coefficient estimate for de facto JI does not change after adding more control variables.

The fact that the estimates for de facto JI are almost identical to the previous results-even though we use a different time period and a larger country sample than in Feld and Voigt (2003) - is reassuring. And because the two studies use an identical questionnaire, we can go one step further and discover whether improvements in JI at a given level of JI in the first wave are associated with higher growth rates. We find that countries that improved their de facto scores for a given initial level of JI grow faster, whereas improvements in the de jure indicator exhibit no statistically significant effect. These results are reported in Table 4.

$<$ Table 4 about here $>>$

We conclude that de jure $\mathrm{JI}$ is never statistically significant, whereas de facto $\mathrm{JI}$ is robustly significant for explaining differences in average growth rates between countries. De facto JI is not only statistically but also economically significant.

\subsection{Interaction with Additional Variables}

In this paper we view JI as an instrument with which the government can credibly commit to its own promises. Alternative instruments for this purpose include the separation of powers and federalism (as a way to separate powers vertically). Generally, compared to autocracies, democracies might have fewer credibility problems, implying that autocracies will profit relatively more than democracies from high levels of JI-if JI is actually implemented.

In the theory section of this paper, we briefly discussed two conflicting hypotheses regarding the effect of form of government in democracies. The conventional view is that presidential democracies are characterized by a stronger separation of powers, which should give these governments a higher commitment capacity. The alternative view is that the president's dominant role could lead to an abuse of power, resulting in instability and slower economic develone end of the spectrum to the other. Improving de facto JI by one standard deviation implies a predicted increase in the average annual growth rate of 0.3 percentage points. 
opment. Finally, the presence of a free press might reinforce JI and its effects, as transparency makes it more costly for government to interfere in the realm of the judiciary.

$<<$ Table 5 about here $>>$

Table 5 begins with the interaction between de facto JI and the variable "checks" from the Database of Political Institutions (Keefer and Stasavage 2003), which proxies for the actually realized degree of checks and balances. We find that the interaction term is significant and that there is a complementary relationship between the two. Consequently, we would predict a positive effect of de facto JI in countries with a level of 3 or more in checks and balances. At a level of 3, we estimate a marginal effect on the growth rate of 1.3 percentage points, which would further increase with higher levels of "checks." When we interact de facto JI with a dummy for federally constituted states, a dummy for bicameralism, or the level of press freedom, we find substitutive relationships in each case. ${ }^{10}$ Therefore, it could be argued that judicial independence is effective in promoting growth only in the absence of federalism, bicameralism, and freedom of the press. However, the difference is not statistically significant for any of them.

When the continuous democracy indicator (polity2) by Marshall et al. (2013) is interacted with de facto $\mathrm{JI}$, the interaction term is not statistically significant, and this does not change when a dichotomous democracy variable by Cheibub et al. (2010) is employed instead. ${ }^{11}$ Yet, when we differentiate democracies according to their form of government, we find a growthenhancing effect of de facto JI in semi-presidential democracies, which benefit significantly more from having an independent judiciary than does any other form of government. Autocracies benefit the least from JI. Another interesting result is that in the complete absence of JI, semi-presidential democracies grow less than any other form of government. Thus, these countries might not only benefit substantially from but may even depend on a de facto independent judiciary.

Finally, we interact de facto JI with the level of initial income to see whether its effect depends on the country's level of development; the interaction term is insignificant. Hence, it does not seem to matter whether a country is poor or rich: the effect of de facto JI will be the same. ${ }^{12}$ by the Inter-Parliamentary Union (2013). Freedom of the press is measured by Freedom House (2013).

12 This result can be used to rebut the allegation made by Rios-Figueroa and Staton (2012) that Feld and Voigt's (2003) dataset suffers from a sample selection problem in the sense that poor countries are underrepresented. The interaction effect indicates that this should not be a problem. 


\subsection{Reliability of the Indicators}

As noted above, countries are given a de facto score only if we have information on at least three of the eight components comprising de facto JI. This decision is of course arbitrary. Therefore, as a final test of robustness, we change this threshold. Among the countries for which the de facto indicator is based on exactly three variables Armenia, Azerbaijan, and Iran have scores substantially above the level one might expect. Leaving out all nine countries where the index is based on three components, the coefficient estimate on de facto JI increases to 1.53 and stays significant (results available on request). The inclusion of countries with incomplete answers in the de facto section of the survey seems to produce more conservative results.

\section{Conclusions and Open Questions}

Based on a questionnaire answered by local experts, we construct a de jure and a de facto indicator for JI. Since exactly the same questionnaire was used in a previous study (Feld and Voigt 2003), we now have information on the change in both de jure and de facto JI for a large number of countries. The findings of the previous paper are confirmed: de jure JI does not have a significant influence on growth, whereas de facto JI does-very significantly and robustly. Based on the differences in de facto JI between the two waves, we find that improvements in de facto JI at given levels in the first wave are associated with higher growth rates.

With respect to the relationship between de facto JI and other attributes of the political system, we find that the realized level of checks and balances complements a high level of de facto JI. The growth performance of semi-presidential democratic countries appears to depend heavily on the presence of an actually independent judiciary. And finally, the growthenhancing effect of de facto JI is independent of a country's income level, that is, poor countries benefit from high levels of de facto JI just as much as high-income countries.

This paper adds to the evidence that de facto JI and economic growth are significantly and robustly correlated and employs objective indicators of JI to do so. Now there are follow-up questions to be answered. Given that JI induces faster growth, what are the exact transmission channels through which this effect manifests? Further: What is the exact relationship between judicial independence on the one hand and judicial accountability on the other? And how does the independence of the judiciary interact with the independence of other important actors who belong to the "justice system" of government, such as the police, the prosecutors, bailiffs, prison guards, and so on? 
Note: First and foremost, the authors thank all the legal experts who often lavishly contributed their time. Without them, this study would not have been possible. Nora El-Bialy coded all the questionnaires underlying this study. Voigt thanks the Notre Dame Institute for Advanced Study where he wrote his part of the paper while there as a Distinguished Guest Fellow. The usual disclaimer applies.

Individuals: Jorge Alberto Fierro Abella (Colombia), Agresta (The Agresta Firm - New York, United States of America), Kofi Akainyah (A \& A Law Consult, Ghana), Tarik H. Arida (Arida Law Firm, Jordan), Irena Bachanovikj (Macedonia), Roger Ballard-Tremeer (The Republic of Angola), Guy J. Bandana Guerrero (GUY JOSE BENDANA-GUERRO \& ASOCIADOS, Nicaragua), Chen Bao (Belgium), Sabela Oubina Barbolla (Carlos III University, Spain), Santiago Basabe-Serrano (Department of Political Studies. Facultad Lantinoamericana de Ciencias Sociales, FLASCO Ecuador, Ecuador), Alvaro Pinto, Basto (CGA, Mozambique), Bessem Ben Salem (Ben Salem Law Firm, Tunesia), Jona Bica (KALO \& ASSOCIATES, Law Firm Tirana, Albania, Republic of Albania), Ignacio Cofone (Argentina), Safa Mustafa Durakoglu (Turkey), Adnan Durakovic (Bosnia and Herzegovina), Alberto E. Fiallo S. (Fiallo-Billini Scanlon Law Firm, Dominican Republic), Aprilda Fiona (Aprilda Fiona \& Partners Law Firm, Indonesia), Santiago Fiorito (PAGBAM IP, Argentina), Luciano Felício Fuck (Brazil), Grace R. Gamez (PARLADE HILDAWA PARLADE ECO \& PANGA, Philippines), Fabien Gélinas (McGill University Faculty of Law, Canada), Khagesh Guatam (Siddhartha K. Garg, India), Juraj Gyarfas (Slovakia), Sileshi Bedasie Hirko (Harmaya University College Law Ethiopia, Ethiopia), Pavel Holec (Holec, Zuska \& Partners, attorneys, Prague, Czech Republic), Nikolaos Intzesiloglou (Aristotle University of Thessaloniki, Greece), Raphael Jakob (MCI Law Firm, Madagascar), Joan M. Javier (Javier Law Office, Philippines), Guatam Jayasurya (Rajiv Gandhi National University of Law, Punjab, India), Rachel Avellar Sotomaior, Karam (Brazil), Mirjana Kovacevic (Serbia), Katleen Krueger (gtz, Tadschikistan), Youjin Lee (Korea), Sandra Isabel Solis Lemus (Mexico), Giacomo Luchetta (Centre for European Policy Studies, Italy), James Macbeth (Armenia), Kate Malleson (Queen Mary, University of London, England and Wales), Diego Marting Menjivar (Consortium Centro America Abogados, El Salvador), Issam AW Mohamed (Sudan), Bianca Mostacatto (Brazil), Zuzana Nehajova (Slovakia), Adetola Olulenu (Nigeria), Vladimir Palamarciuc (Associate, Turcan Cazac Law Firm, Moldova), Dámaso A. Pardo (PAGBAM IP, Argentina), Michael Pikramenos (Aristotle University of Thessaloniki, Greece), Evangelia Podimata (Aristotle University of Thessaloniki, Greece), László Pók (Szecskay Attorneys at Law, Hungary), Amnon Reichmann (Faculty of Law, Universty of Haifa, Israel), K. S., Reimann (Germany), Renny Reyes (Dominican Republic), Valerio Cosmio Romano (Italy), Maya Segal (Israel), Alexander Turcan (Managing Partner, Turcan Cazac Law Firm, Moldova), Anurag Tripathi (National Law Universtiy Orissa, India), Basil Ugochukwu (Osgoode Hall Law School, Toronto, Nigeria), Alberto Vega (Spain), Wolfgang Weigel (Austria), Simon Weldehaimanot (Eritrea).

Corporate entities: A \& A Law Consult (Ghana), AHK Zentalasien (Uzbekistan), ARGUELLES \& COMPANY (Belize), Attorney at Law of Lehman Lee \& Xu (China), Connelly International Legal Counsellors Thailand Ltd. (Thailand), Consortium Centroamérica Abogados-Honduras (Honduras), Dinova Rusev\&Partners Law Office, Sofia (Bulgaria), Dmitry Kravchenko, Maxim Shishkov, Moscow Branch of Association of Lawyers of Russia (Russian Federation), ETWAH-NAN \& $\mathrm{C}^{\circ}$ (Attorneys) (Cameroon), Frans Winarta \& Partners (Indonesia), GRATA Law Firm (Kazakhstan), Karanovic \& Nikolic Law Firm, Milena Roncevic associate (Montenegro), Konrad-Adenauer-Stiftung, Uganda Office (Uganda), Law firm "SAJIC" g.p. Banja Luka (Bosnia and Herzegovina), Lawyer at Rabat bar, President Adala association (Morocco), Refik N. Türkoglu \& Partner (Turkey), SBA legal firm and I\&D Consulting (El Salvador, CA), SCPA DOUGUE-Abbé YAO \& Associés (Ivory Coast), SOTERIS PITTAS \& CO LLC (Cyprus), Sworn Attorneys Office "LAWIN", Riga (Latvia), The Abeng Law Firm (Cameroon), Universidad Technológica Centroamericana (Honduras), VNA LEGAL (Lao People's Democratic Republic). 


\section{References}

Aaken, A. v., L. P. Feld, and S. Voigt (2010); Do Independent Prosecutors Deter Political Corruption? An Empirical Evaluation Across 78 Countries, American Law and Economics Review 12:204-44.

Acemoglu, D. and S. Johnson (2005); Unbundling Institutions, Journal of Political Economy 113:94995.

Arnone, M., B. Laurens, and J.-F. Segalotto (2006); The Measurement of Central Bank Autonomy: Survey of Models, Indicators, and Empirical Evidence, IMF Working Paper WP/06/227.

Asatryan, Z. and L. P. Feld (2013); Revisiting the Link Between Growth and Federalism: A Bayesian Model Averaging Approach, forthcoming in: Journal of Comparative Economics, DOI: 10.1016/j.jce.2014.04.005.

Barro, R. J. and J. W. Lee (2013); A New Data Set of Educational Attainment in the World, 19502010, Journal of Development Economics 104:184-98.

Baskaran, T. and L. P. Feld (2013); Fiscal Decentralization and Economic Growth in OECD Countries: Is There a Relationship?, Public Finance Review 41:421-45.

Berger, H., J. de Haan, and S. Eijffinger (2001); Central Bank Independence: An Update of Theory and Evidence, Journal of Economic Surveys 15:3-40.

Blume, L., J. Müller, and S. Voigt (2009); The Economic Effects of Direct Democracy: A First Global Assessment, Public Choice 140:431-61.

Cheibub, J. A., J. Gandhi, and J. R. Vreeland (2010). Democracy and Dictatorship Revisited, Public Choice 143:67-101.

Cukierman, A. (1992); Central Bank Strategy, Credibility, and Independence, Cambridge: MIT Press.

Cukierman, A., S. Webb, and B. Neyapti (1992); Measuring the Independence of Central Banks and its Effects on Policy Outcomes, World Bank Economic Review 6:353-98.

Debelle, G. and S. Fischer (1995); How Independent Should a Central Bank Be? In: J. C. Fuhrer (ed.); Goals, Guidelines and Constraints Facing Monetary Policymakers, Federal Reserve Bank of Boston, Conference Series No. 38, Boston, 195-221.

Feenstra, R. C., R. Inklaar, and M. P. Timmer (2013); The Next Generation of the Penn World Table, NBER Working Paper 19255.

Feld, L. P., G. Kirchgässner, and C. A. Schaltegger (2005); Fiskalischer Föderalismus und wirtschaftliche Entwicklung: Evidenz für die Schweizer Kantone, Jahrbuch für Regionalwissenschaft/Review of Regional Research 25:3-25.

Feld, L. P. and M. R. Savioz (1997); Direct Democracy Matters for Economic Performance: An Empirical Investigation, Kyklos 50:507-38.

Feld, L. P. and S. Voigt (2003); Economic Growth and Judicial Independence: Cross Country Evidence Using a New Set of Indicators, European Journal of Political Economy 19:497-527.

Freedom House (2013); Freedom of the Press, available at: http://www.freedomhouse.org/reporttypes/freedom-press.

Ginsburg, T. and J. Melton (2012); Does De Jure Independence Really Matter? A Reevaluation of Explanations for Judicial Independence, available at: http://papers.ssrn.com/sol3/papers.cfm?abstract_id=2104512. 
Grilli, V., D. Masciandaro, and G. Tabellini (1991); Political and Monetary Institutions and Public Financial Policies in the Industrial Countries, Economic Policy 13:341-92.

Hanretty, C. and C. Koop (2012); Measuring the Formal Independence of Regulatory Agencies, Journal of European Public Policy 19:198-216.

Hanretty, C. and C. Koop (2013); Shall the Law Set Them Free? The Formal and Actual Independence of Regulatory Agencies, Regulation \& Governance 7:195-214.

Hanssen, F. A. (2004); Is There a Politically Optimal Level of Judicial Independence? American Economic Review 94:712-29.

Hayo, B. and C. Hefeker (2002); Reconsidering Central Bank Independence, European Journal of Political Economy 18:653-74.

Hayo, B. and S. Voigt (2008); Inflation, Central Bank Independence and the Legal System, Journal of Institutional and Theoretical Economics 164:751-77.

Hayo, B. and S. Voigt (2012); Explaining Constitutional Change: The Case of Judicial Independence, CESifo Working Paper Series 4032.

Hobbes, T. (1651); De Cive-Philosophical Rudiments Concerning Government and Society, available at: http://www.constitution.org/th/decive.htm.

Inter-Parliamentary Union (2013); Structure of Parliaments, available at: http://www.ipu.org/parlinee/ParliamentsAtaGlance.asp.

Keefer, P. and D. Stasavage (2003); The Limits of Delegation: Veto Players, Central Bank Independence and the Credibility of Monetary Policy, American Political Science Review 97:407-23.

Klomp, J. and J. de Haan (2010); Inflation and Central Bank Independence: A Meta-Regression Analysis, Journal of Economic Surveys 24:593-621.

Law, D. S. and M. Versteeg (2013); Sham Constitutions, California Law Review 101:863-952.

Majone, G. (2001); Nonmajoritarian Institutions and the Limits of Democratic Governance: A Political Transaction-Cost Approach, Journal of Institutional and Theoretical Economics 157:57-78.

Marshall, M. G., T. R. Gurr, and K. Jaggers (2013); Polity IV Project: Political Regime Characteristics and Transitions, 1800-2012, available at: http://www.systemicpeace.org.

McCubbins, M. D. and D. B. Rodriguez (2006); The Judiciary and the Role of Law. In: Weingast, B. and D. Wittman (eds.); The Oxford Handbook of Political Economy, Oxford: Oxford University Press, 273-86.

Norris, P. (2009); Democracy Timeseries Data Release 3.0, available at: http://www.pippanorris.com.

Padovano, F. and N. Fiorina (2012); Strategic Delegation and "Judicial Couples" in the Italian Constitutional Court, International Review of Law \& Economics 32:215-23.

Persson, T., G. Roland, and G. Tabellini (1997); Separation of Powers and Political Accountability, Quarterly Journal of Economics 112:310-27.

Persson, T. and G. Tabellini (2003); The Economic Effects of Constitutions, Cambridge: MIT Press.

Rios-Figueroa, J. and J. K. Staton (2012); An Evaluation of Cross-National Measures of Judicial Independence, Journal of Law, Economics, and Organization 30:104-37. 
Tsebelis, G. (2002); Veto Players: How Political Institutions Work, Princeton: Princeton University Press.

Voigt, S. (2009); The Effects of Competition Policy on Development: Cross-Country Evidence Using Four New Indicators, Journal of Development Studies 45:1225-48.

Voigt, S. (2011); Positive Constitutional Economics II: A Survey of Recent Developments, Public Choice 146:205-56.

Voigt, S. and L. Blume (2012); The Economic Effects of Federalism and Decentralization: A CrossCountry Assessment, Public Choice 151:229-54.

Voigt, S. and J. Gutmann (2013); Turning Cheap Talk into Economic Growth: On the Relationship Between Property Rights and Judicial Independence, Journal of Comparative Economics 41:6673.

Watts, R. L. (1998); Federalism, Federal Political Systems, and Federations, Annual Review of Political Science 1:117-37.

Weingast, B. R. (1993); Constitutions as Governance Structures: The Political Foundations of Secure Markets, Journal of Institutional and Theoretical Economics 149:286-311.

Yohai, V. J. (1987); High Breakdown-Point and High Efficiency Robust Estimates for Regression, Annals of Statistics 15:642-56. 
Table 2: Descriptive Statistics

\begin{tabular}{|c|c|c|c|c|c|}
\hline Variable & Obs & Mean & Std. Dev. & Min & $\operatorname{Max}$ \\
\hline Economic Growth & 104 & 2.267 & 1.763 & -4.044 & 9.252 \\
\hline Initial Income & 104 & 9.081 & 8.493 & 0.336 & 32.569 \\
\hline Education & 104 & 17.863 & 12.543 & 0.549 & 57.837 \\
\hline Investment & 104 & 20.327 & 6.696 & 5.704 & 40.720 \\
\hline Transition Country & 104 & 0.173 & 0.380 & 0 & 1 \\
\hline De Jure JI & 104 & 0.633 & 0.142 & 0.300 & 0.934 \\
\hline De Facto JI & 104 & 0.631 & 0.234 & 0.133 & 1.000 \\
\hline Population Growth & 104 & 1.288 & 1.085 & -1.008 & 3.665 \\
\hline Trade Openness & 104 & 74.399 & 46.067 & 20.870 & 336.528 \\
\hline Government Size & 104 & 18.908 & 8.201 & 5.683 & 50.611 \\
\hline Inflation Rate & 102 & 56.864 & 209.987 & -0.349 & 1979.170 \\
\hline De Jure JI (Old) & 81 & 0.629 & 0.161 & 0.159 & 0.939 \\
\hline De Facto JI (Old) & 70 & 0.565 & 0.234 & 0.133 & 1.000 \\
\hline De Jure JI Difference & 81 & 0.013 & 0.155 & -0.483 & 0.373 \\
\hline De Facto JI Difference & 70 & 0.078 & 0.267 & -0.383 & 0.727 \\
\hline Checks & 100 & 3.330 & 1.491 & 1 & 8 \\
\hline Federalism & 103 & 0.155 & 0.364 & 0 & 1 \\
\hline Bicameralism & 104 & 0.471 & 0.502 & 0 & 1 \\
\hline Press Freedom & 103 & 41.936 & 22.196 & 8.625 & 83.875 \\
\hline Democracy (Polity) & 101 & 5.137 & 5.168 & -7 & 10 \\
\hline Democracy (DD) & 103 & 0.738 & 0.442 & 0 & 1 \\
\hline Autocracy & 103 & 0.262 & 0.442 & 0 & 1 \\
\hline Presidential Democracy & 103 & 0.282 & 0.452 & 0 & 1 \\
\hline Semi-Pres. Democracy & 103 & 0.184 & 0.390 & 0 & 1 \\
\hline Parliamentary Democracy & 103 & 0.272 & 0.447 & 0 & 1 \\
\hline
\end{tabular}

Note: Sample based on Column (4) in Table 3. 
Table 3: Judicial Independence and Economic Growth

\begin{tabular}{|c|c|c|c|c|c|c|}
\hline & (1) & (2) & (3) & (4) & (4-MM) & (5) \\
\hline Initial Income & $\begin{array}{c}-0.069^{* * *} \\
(0.020)\end{array}$ & $\begin{array}{c}-0.069 * * \\
(0.020)\end{array}$ & $\begin{array}{c}-0.074 * * * \\
(0.020)\end{array}$ & $\begin{array}{c}-0.074 * * * \\
(0.020)\end{array}$ & $\begin{array}{c}-0.080^{* * *} \\
(0.017)\end{array}$ & $\begin{array}{c}-0.095^{* * * *} \\
(0.023)\end{array}$ \\
\hline Education & $\begin{array}{c}0.008 \\
(0.015)\end{array}$ & $\begin{array}{c}0.008 \\
(0.015)\end{array}$ & $\begin{array}{c}0.006 \\
(0.014)\end{array}$ & $\begin{array}{c}0.006 \\
(0.014)\end{array}$ & $\begin{array}{c}0.016 \\
(0.018)\end{array}$ & $\begin{array}{c}0.011 \\
(0.015)\end{array}$ \\
\hline Investment & $\begin{array}{c}0.128^{* * *} \\
(0.023)\end{array}$ & $\begin{array}{c}0.128^{* * *} \\
(0.023)\end{array}$ & $\begin{array}{c}0.126^{* * *} \\
(0.022)\end{array}$ & $\begin{array}{c}0.127^{* * *} \\
(0.023)\end{array}$ & $\begin{array}{c}0.108^{* * *} \\
(0.033)\end{array}$ & $\begin{array}{c}0.131^{* * *} \\
(0.026)\end{array}$ \\
\hline Transition Country & $\begin{array}{l}-0.218 \\
(0.407)\end{array}$ & $\begin{array}{l}-0.213 \\
(0.409)\end{array}$ & $\begin{array}{l}-0.181 \\
(0.399)\end{array}$ & $\begin{array}{l}-0.177 \\
(0.401)\end{array}$ & $\begin{array}{c}0.138 \\
(0.437)\end{array}$ & $\begin{array}{l}-0.113 \\
(0.571)\end{array}$ \\
\hline De Jure JI & & $\begin{array}{l}-0.213 \\
(0.929)\end{array}$ & & $\begin{array}{l}-0.154 \\
(0.910)\end{array}$ & $\begin{array}{l}-0.338 \\
(1.534)\end{array}$ & $\begin{array}{l}-0.768 \\
(0.936)\end{array}$ \\
\hline De Facto JI & & & $\begin{array}{l}1.286^{*} \\
(0.566)\end{array}$ & $\begin{array}{l}1.283^{*} \\
(0.569)\end{array}$ & $\begin{array}{l}1.680^{*} \\
(0.707)\end{array}$ & $\begin{array}{l}1.341^{*} \\
(0.577)\end{array}$ \\
\hline Population Growth & & & & & & $\begin{array}{l}-0.132 \\
(0.207)\end{array}$ \\
\hline Trade Openness & & & & & & $\begin{array}{l}-0.004 \\
(0.004)\end{array}$ \\
\hline Government Size & & & & & & $\begin{array}{c}0.006 \\
(0.020)\end{array}$ \\
\hline Inflation Rate & & & & & & $\begin{array}{c}-0.004^{*} \\
(0.002)\end{array}$ \\
\hline Constant & $\begin{array}{c}0.172 \\
(0.447)\end{array}$ & $\begin{array}{c}0.291 \\
(0.685)\end{array}$ & $\begin{array}{l}-0.546 \\
(0.540)\end{array}$ & $\begin{array}{l}-0.459 \\
(0.748)\end{array}$ & $\begin{array}{l}-0.357 \\
(1.628)\end{array}$ & $\begin{array}{c}0.354 \\
(1.067)\end{array}$ \\
\hline Outlier Dummies & YES & YES & YES & YES & $\mathrm{NO}$ & YES \\
\hline Observations & 104 & 104 & 104 & 104 & 104 & 102 \\
\hline Adjusted- $\mathrm{R}^{2}$ & 0.459 & 0.453 & 0.481 & 0.476 & & 0.486 \\
\hline
\end{tabular}

Note: (1)-(4)\&(5): OLS coefficient estimates, standard errors in parentheses, *: $\mathrm{p}<0.05$, **: $\mathrm{p}<0.01$, ***: $\mathrm{p}<0.001$. Coefficient estimates on dummies for China, DR Congo, and Trinidad \& Tobago omitted. (4-MM): MM-estimator by Yohai (1987), standard errors in parentheses.

Table 4: Differences in JI and Economic Growth

\begin{tabular}{lccc}
\hline & $\mathbf{( 1 )}$ & $\mathbf{( 2 )}$ & $\mathbf{( 3 )}$ \\
\hline De Jure JI (Old) & -1.923 & $-2.129^{*}$ & -1.767 \\
& $(1.107)$ & $(0.859)$ & $(1.035)$ \\
De Facto JI (Old) & 0.243 & $1.610^{*}$ & $1.564^{*}$ \\
& $(0.649)$ & $(0.732)$ & $(0.739)$ \\
De Jure JI Difference & 0.522 & & 0.668 \\
& $(1.125)$ & & $(1.052)$ \\
De Facto JI Difference & & $1.793^{* *}$ & $1.809^{* *}$ \\
& & $(0.576)$ & $(0.580)$ \\
Initial Income & $-0.087^{* * *}$ & $-0.096^{* * *}$ & $-0.093^{* * *}$ \\
& $(0.021)$ & $(0.019)$ & $(0.019)$ \\
Education & 0.024 & 0.024 & 0.025 \\
& $(0.014)$ & $(0.013)$ & $(0.013)$ \\
Investment & $0.100^{* * *}$ & $0.112^{* * *}$ & $0.110^{* * *}$ \\
Transition Country & $(0.024)$ & $(0.022)$ & $(0.023)$ \\
& -0.169 & -0.145 & -0.177 \\
Constant & $(0.430)$ & $(0.397)$ & $(0.402)$ \\
& $1.800^{*}$ & 0.856 & 0.646 \\
Outlier Dummies & $(0.840)$ & $(0.798)$ & $(0.868)$ \\
Observations & YES & YES & YES \\
Adjusted-R ${ }^{2}$ & 70 & 70 & 70 \\
\hline Note: See Table 3, coeffic & 0.516 & 0.582 & 0.578 \\
\hline
\end{tabular}

Note: See Table 3, coefficient estimates on dummies for China and Trinidad \& Tobago omitted. 
Table 5: Judicial Independence, Constitutional Traits, and Economic Growth

\begin{tabular}{|c|c|c|c|c|c|c|}
\hline & (1) & (2) & (3) & (4) & (5) & (6) \\
\hline De Jure JI & $\begin{array}{c}-0.581 \\
(0.940)\end{array}$ & $\begin{array}{l}-0.052 \\
(0.917)\end{array}$ & $\begin{array}{l}-0.133 \\
(0.912)\end{array}$ & $\begin{array}{l}-0.476 \\
(0.988)\end{array}$ & $\begin{array}{l}-0.362 \\
(1.001)\end{array}$ & $\begin{array}{l}-0.154 \\
(0.916)\end{array}$ \\
\hline De Facto JI & $\begin{array}{l}-1.501 \\
(1.249)\end{array}$ & $\begin{array}{l}1.653^{*} \\
(0.629)\end{array}$ & $\begin{array}{l}2.155^{*} \\
(0.830)\end{array}$ & $\begin{array}{c}2.062 \\
(1.396)\end{array}$ & $\begin{array}{c}0.219 \\
(0.892)\end{array}$ & $\begin{array}{c}1.279 \\
(0.776)\end{array}$ \\
\hline Checks & $\begin{array}{c}-0.528^{*} \\
(0.262)\end{array}$ & & & & & \\
\hline df-JI*Checks & $\begin{array}{l}0.949^{*} \\
(0.388)\end{array}$ & & & & & \\
\hline Federalism & & $\begin{array}{c}1.099 \\
(1.001)\end{array}$ & & & & \\
\hline df-JI*Federalism & & $\begin{array}{l}-2.311 \\
(1.463)\end{array}$ & & & & \\
\hline Bicameralism & & & $\begin{array}{c}0.866 \\
(0.771)\end{array}$ & & & \\
\hline df-JI*Bicameralism & & & $\begin{array}{l}-1.643 \\
(1.141)\end{array}$ & & & \\
\hline Press Freedom & & & & $\begin{array}{c}0.005 \\
(0.020)\end{array}$ & & \\
\hline df-JI*Press Freedom & & & & $\begin{array}{l}-0.019 \\
(0.026)\end{array}$ & & \\
\hline Presidential & & & & & $\begin{array}{l}-0.596 \\
(0.933)\end{array}$ & \\
\hline Semi-Presidential & & & & & $\begin{array}{c}-3.288^{* *} \\
(1.178)\end{array}$ & \\
\hline Parliamentary & & & & & $\begin{array}{l}-0.371 \\
(1.160)\end{array}$ & \\
\hline df-JI*Presidential & & & & & $\begin{array}{c}0.308 \\
(1.379)\end{array}$ & \\
\hline df-JI*Semi-Presidential & & & & & $\begin{array}{c}5.099 * * \\
(1.709)\end{array}$ & \\
\hline df-JI*Parliamentary & & & & & $\begin{array}{c}0.514 \\
(1.659)\end{array}$ & \\
\hline df-JI*Initial Income & & & & & & $\begin{array}{c}0.001 \\
(0.073)\end{array}$ \\
\hline Constant & $\begin{array}{c}1.562 \\
(1.006) \\
\end{array}$ & $\begin{array}{l}-0.668 \\
(0.770)\end{array}$ & $\begin{array}{l}-0.871 \\
(0.819)\end{array}$ & $\begin{array}{l}-0.420 \\
(1.445) \\
\end{array}$ & $\begin{array}{c}0.623 \\
(0.860)\end{array}$ & $\begin{array}{l}-0.457 \\
(0.810)\end{array}$ \\
\hline $\begin{array}{l}\text { F statistic } \\
\text { p-value }\end{array}$ & $\begin{array}{c}5.52 \\
0.006\end{array}$ & $\begin{array}{c}3.58 \\
0.032\end{array}$ & $\begin{array}{c}3.60 \\
0.031\end{array}$ & $\begin{array}{c}2.24 \\
0.112\end{array}$ & $\begin{array}{c}3.51 \\
0.011\end{array}$ & $\begin{array}{c}2.52 \\
0.086\end{array}$ \\
\hline $\begin{array}{l}\text { Outlier Dummies } \\
\text { Observations } \\
\text { Adjusted } \mathrm{R}^{2}\end{array}$ & $\begin{array}{c}\text { YES } \\
100 \\
0.489\end{array}$ & $\begin{array}{c}\text { YES } \\
103 \\
0.483\end{array}$ & $\begin{array}{c}\text { YES } \\
104 \\
0.479\end{array}$ & $\begin{array}{l}\text { YES } \\
103 \\
0.471\end{array}$ & $\begin{array}{c}\text { YES } \\
103 \\
0.503\end{array}$ & $\begin{array}{l}\text { YES } \\
104 \\
0.470\end{array}$ \\
\hline
\end{tabular}

Note: See Table 3, coefficient estimates on initial income, investment, education, and transition country, as well as on dummies for China, DR Congo, and Trinidad \& Tobago, omitted. F statistic reported for joint test of de facto JI and all interaction terms in the model. 
Appendix 1: Indicators of Judicial Independence

\begin{tabular}{|c|c|c|c|c|}
\hline Country & De Jure (Old) & De Jure (New) & De Facto (Old) & De Facto (New) \\
\hline Albania & & 0.828 & & 0.508 \\
\hline Angola & & 0.783 & & \\
\hline Argentina & 0.665 & 0.722 & 0.333 & 0.167 \\
\hline Armenia & 0.629 & 0.584 & 1.000 & 1.000 \\
\hline Australia & 0.817 & 0.575 & 0.819 & 0.870 \\
\hline Austria & 0.733 & 0.655 & 0.900 & 0.743 \\
\hline Azerbaijan & 0.451 & 0.638 & & 0.867 \\
\hline Bahamas & 0.646 & & 0.450 & \\
\hline Bangladesh & 0.587 & 0.586 & 0.429 & 0.294 \\
\hline Belarus & & 0.452 & & 0.300 \\
\hline Belgium & 0.825 & 0.629 & 0.806 & \\
\hline Belize & & 0.599 & & 0.503 \\
\hline Benin & 0.691 & 0.445 & 0.550 & 0.757 \\
\hline Bolivia & 0.726 & 0.634 & 0.560 & 0.333 \\
\hline Bosnia and Herzegovina & & 0.844 & & 0.480 \\
\hline Botswana & 0.841 & 0.825 & 0.414 & 0.960 \\
\hline Brazil & 0.907 & 0.712 & 0.494 & 0.825 \\
\hline Bulgaria & 0.397 & 0.762 & 0.133 & 0.667 \\
\hline Cambodia & 0.341 & 0.504 & 0.200 & 0.708 \\
\hline Cameroon & & 0.690 & & 0.233 \\
\hline Canada & 0.681 & 0.733 & & 0.714 \\
\hline Chile & 0.778 & 0.788 & 0.575 & 0.710 \\
\hline China & 0.406 & 0.554 & 0.370 & 0.417 \\
\hline Colombia & 0.939 & 0.779 & 0.529 & 0.486 \\
\hline Congo, Democratic Republic & & 0.599 & & 0.267 \\
\hline Costa Rica & 0.685 & 0.621 & 0.920 & 0.933 \\
\hline Cote d'Ivoire & 0.507 & 0.678 & 0.433 & 0.600 \\
\hline Croatia & 0.570 & 0.671 & 0.657 & 0.350 \\
\hline Cyprus & 0.817 & 0.742 & 0.743 & 0.400 \\
\hline Czech Republic & 0.761 & 0.739 & 0.167 & 0.717 \\
\hline Denmark & 0.779 & 0.712 & 0.813 & 0.650 \\
\hline Dominican Republic & 0.839 & 0.753 & & 0.750 \\
\hline Ecuador & 0.835 & 0.738 & 0.388 & 0.375 \\
\hline Egypt & 0.708 & 0.715 & 0.240 & 0.967 \\
\hline El Salvador & & 0.634 & & 0.381 \\
\hline Equatorial Guinea & & 0.364 & & 0.550 \\
\hline Eritrea & & 0.628 & & \\
\hline Estonia & 0.641 & 0.842 & 0.700 & 0.731 \\
\hline Ethiopia & & 0.656 & & 0.217 \\
\hline Fiji & 0.729 & & 0.436 & \\
\hline Finland & 0.544 & 0.587 & 0.450 & 0.560 \\
\hline France & 0.634 & 0.689 & 0.786 & 0.607 \\
\hline Georgia & 0.893 & 0.754 & 0.850 & 0.850 \\
\hline Germany & 0.729 & 0.781 & 0.800 & 0.943 \\
\hline Ghana & 0.464 & 0.525 & 0.300 & 0.800 \\
\hline Greece & 0.833 & 0.843 & 0.500 & 0.481 \\
\hline Guatemala & 0.499 & 0.465 & 0.529 & 0.481 \\
\hline Guyana & & 0.696 & & \\
\hline Haiti & 0.538 & & & \\
\hline Honduras & 0.555 & 0.575 & & 0.638 \\
\hline Hong Kong & & 0.812 & & 0.950 \\
\hline Hungary & 0.628 & 0.688 & 0.821 & 0.594 \\
\hline Iceland & 0.554 & 0.454 & 0.675 & 0.360 \\
\hline India & 0.629 & 0.804 & 0.708 & 0.750 \\
\hline Indonesia & 0.300 & 0.528 & & 0.631 \\
\hline Iran & & 0.485 & & 0.933 \\
\hline
\end{tabular}




\begin{tabular}{|c|c|c|c|c|}
\hline Ireland & & 0.677 & & 0.950 \\
\hline Israel & 0.663 & 0.679 & 0.860 & 0.650 \\
\hline Italy & 0.793 & 0.858 & 0.858 & 0.944 \\
\hline Japan & 0.622 & 0.614 & 0.900 & 0.517 \\
\hline Jordan & 0.573 & 0.604 & 0.200 & 0.267 \\
\hline Kazakhstan & 0.538 & 0.362 & & \\
\hline Kenya & 0.709 & 0.785 & 0.175 & 0.543 \\
\hline Korea, South & 0.607 & 0.663 & 0.588 & 0.463 \\
\hline Kuwait & 0.574 & & 1.000 & \\
\hline Kyrgyzstan & & 0.599 & & 0.669 \\
\hline Laos & & 0.307 & & 0.850 \\
\hline Latvia & & 0.658 & & 0.600 \\
\hline Lebanon & & 0.496 & & 0.433 \\
\hline Lesotho & & 0.769 & & 0.867 \\
\hline Liberia & & 0.633 & & 1.000 \\
\hline Lithuania & 0.447 & 0.619 & 0.433 & 0.875 \\
\hline Macedonia & & 0.714 & & 0.536 \\
\hline Madagascar & 0.468 & 0.651 & 0.800 & 0.669 \\
\hline Malawi & & 0.521 & & 0.500 \\
\hline Malaysia & 0.313 & 0.389 & 0.270 & 0.270 \\
\hline Mauritania & 0.569 & & 0.600 & \\
\hline Mauritius & 0.797 & & & \\
\hline Mexico & 0.804 & 0.778 & 0.707 & 0.719 \\
\hline Moldova & & 0.549 & & 0.550 \\
\hline Mongolia & & 0.706 & & 0.567 \\
\hline Montenegro & 0.465 & 0.750 & 0.100 & 0.536 \\
\hline Morocco & 0.275 & 0.326 & & 0.320 \\
\hline Mozambique & 0.441 & 0.338 & 0.520 & 0.860 \\
\hline Myanmar & & 0.583 & & 0.971 \\
\hline Namibia & 0.684 & 0.362 & & 0.950 \\
\hline Nepal & 0.799 & 0.691 & 0.520 & 0.629 \\
\hline Netherlands & 0.631 & 0.600 & 0.467 & 1.000 \\
\hline New Zealand & 0.587 & 0.625 & 0.783 & 0.800 \\
\hline Nicaragua & 0.357 & 0.603 & 0.320 & 0.300 \\
\hline Niger & 0.423 & & 0.080 & \\
\hline Nigeria & 0.553 & 0.754 & 0.243 & 0.567 \\
\hline Norway & 0.468 & 0.516 & 0.901 & 0.800 \\
\hline Pakistan & 0.765 & 0.748 & 0.525 & 0.183 \\
\hline Panama & 0.572 & & 0.388 & \\
\hline Paraguay & 0.658 & 0.576 & 0.490 & 0.467 \\
\hline Peru & 0.485 & 0.678 & 0.160 & 0.420 \\
\hline Philippines & 0.909 & 0.934 & 0.731 & 0.486 \\
\hline Poland & 0.693 & 0.538 & & 0.880 \\
\hline Portugal & 0.530 & 0.781 & 0.706 & 0.711 \\
\hline Romania & 0.548 & 0.919 & & 0.571 \\
\hline Russia & 0.845 & 0.362 & 0.133 & 0.686 \\
\hline Rwanda & & 0.585 & & 0.133 \\
\hline Senegal & 0.567 & 0.548 & & 0.333 \\
\hline Serbia & & 0.522 & & 0.533 \\
\hline Sierra Leone & & 0.566 & & 0.133 \\
\hline Singapore & 0.851 & 0.548 & 0.421 & 0.936 \\
\hline Slovakia & 0.569 & 0.691 & 0.319 & 0.621 \\
\hline Slovenia & 0.869 & 0.869 & 0.431 & 0.431 \\
\hline South Africa & 0.681 & 0.767 & 0.825 & 0.886 \\
\hline Spain & 0.551 & 0.744 & 0.750 & 0.439 \\
\hline Sri Lanka & 0.476 & 0.527 & 0.813 & 0.943 \\
\hline Sudan & & 0.300 & & 0.829 \\
\hline Sweden & 0.605 & 0.494 & 0.700 & 0.680 \\
\hline Switzerland & 0.459 & 0.490 & 0.943 & 0.933 \\
\hline Taiwan & 0.575 & 0.798 & 0.863 & 0.914 \\
\hline Tajikistan & & 0.407 & & 0.588 \\
\hline Tanzania & 0.265 & 0.638 & & 0.950 \\
\hline
\end{tabular}


Thailand

Trinidad and Tobago

Tunisia

Turkey

Uganda

Ukraine

United Arab Emirates

United Kingdom

United States

Uruguay

Uzbekistan

Vanuatu

Venezuela

Vietnam

Yemen

Zambia

Zimbabwe

$\begin{array}{lll}0.728 & & 0.629 \\ 0.820 & 0.388 & 0.270 \\ 0.602 & & 0.350 \\ 0.795 & 0.800 & 0.743 \\ 0.702 & 0.250 & 0.850 \\ 0.439 & 0.543 & 0.371 \\ 0.531 & & \\ 0.385 & 0.830 & 0.950 \\ 0.534 & 0.592 & 0.543 \\ 0.498 & 0.450 & 0.757 \\ 0.527 & & 0.350 \\ 0.649 & 0.320 & 0.700 \\ 0.438 & 0.400 & 0.333 \\ 0.677 & & 0.533 \\ & 0.400 & \end{array}$


Appendix 2: Variable Description

Variable

Description

\begin{tabular}{|c|c|}
\hline Economic Growth & Average annual growth rate of GDP per capita over the period 1990 to 2008 based on "rgdpna” by Feenstra et al. (2013). \\
\hline Initial Income & GDP per capita in the first year of observation (1990 or later) based on "rgdpe" by Feenstra et al. (2013). \\
\hline Education & Share of the population over 15 with complete secondary education (1990 or later) by Barro and Lee (2013). \\
\hline Investment & Share of investment in GDP based on “csh_i” by Feenstra et al. (2013). \\
\hline Transition Country & Dummy variable coded according to http://www.imf.org/external/np/exr/ib/2000/110300.htm. \\
\hline De Jure JI & Own coding; see Section 4 and Online Appendix for details. \\
\hline De Facto JI & Own coding; see Section 4 and Online Appendix for details. \\
\hline Population Growth & Average annual population growth rate over the period 1990 to 2008 by Feenstra et al. (2013). \\
\hline Trade Openness & Average level of trade openness over the period 1990 to 2008 based on "openk" in the Penn World Table 7.1. \\
\hline Government Size & Share of government consumption in GDP based on “csh_g” by Feenstra et al. (2013). \\
\hline Inflation Rate & Average annual inflation rate over the period 1990 to 2008 in the World Development Indicators. \\
\hline De Jure JI (Old) & Data from Feld and Voigt (2003). \\
\hline De Facto JI (Old) & Data from Feld and Voigt (2003). \\
\hline De Jure JI Difference & De jure JI - De jure JI (old). \\
\hline De Facto JI Difference & De facto JI - De facto JI (old). \\
\hline Checks & Level of checks and balances in 2000 based on "checks" by Keefer and Stasavage (2003). \\
\hline Federalism & Dummy variable (hybrids treated as unitary) by Norris (2009), coded according to Watts (1998). \\
\hline Bicameralism & Dummy variable by the Inter-Parliamentary Union (2013). \\
\hline Press Freedom & Average level of press freedom over the period 1990 to 2008 by Freedom House (2013). \\
\hline Democracy (Polity) & Level of democracy or autocracy on a scale from -10 to +10 by Marshall et al. (2013). \\
\hline Democracy (DD) & Political regime in 2008 based on "democracy" by Cheibub et al. (2010). \\
\hline Autocracy & Political regime in 2008 based on “democracy" by Cheibub et al. (2010). \\
\hline Presidential Democracy & Political regime in 2008 based on "regime" by Cheibub et al. (2010). \\
\hline Semi-Pres. Democracy & Political regime in 2008 based on "regime" by Cheibub et al. (2010). \\
\hline Parliamentary Democracy & Political regime in 2008 based on "regime" by Cheibub et al. (2010). \\
\hline
\end{tabular}


Online Appendix: Questionnaire for Country Experts (augmented with coding rules).

\section{Making Promises Credible- \\ The Independence of Courts \\ QUESTIONNAIRE}

\section{Please return to:}

Prof. Dr. Stefan Voigt

Institute of Law \& Economics

Johnsallee 35

D-20148 Hamburg

Germany

Dear Reader,

This research project is an attempt to make judicial independence measurable and thus comparable across countries. I would be grateful if you could help me with your knowledge concerning the country on which you are an expert and answer the following questions.

If you are interested, I would be pleased to keep you informed on the progress concerning the indicator. In that case, please provide me with your address. Of course, the easiest way to return the questionnaire is by e-mail (Stefan.voigt@unihamburg.de).

Thank you very much for your help. Yours sincerely

Stefan Voigt

Country for which information is provided:

(_) I would like to be informed on the progress of this project, please send up-date information to my e-mail address:

(_) I would like to remain completely anonymous.

(_) I would prefer that my name and/or that of my law firm is mentioned in papers resulting out of this project; I would like it to be mentioned in the following way: 


\section{A de jure measure for court independence}

(1) Is the highest court mentioned in the constitution?

( ) YES ( ) NO

a. Are its competencies enumerated in the constitution?

( ) YES ( ) NO

b. Are its procedures specified in the constitution?

( ) YES ( ) NO

c. Is access to the highest court specified in the constitution?

( ) YES ( ) NO

d. Are the arrangements concerning the members of the highest court enumerated in the constitution?

aa. Is the term length specified in the constitution?

( ) YES ( ) NO

bb. Is the number of judges specified in the constitution?

( ) YES ( ) NO

\section{A GOOD SOURCE FOR MORE DETAILED INFORMATION IS}

(2) How difficult is it to amend the constitution?

a. Is a majority necessary that is above that necessary for changing ordinary legislation?

( ) YES ( ) NO

b. How many branches of government have to agree?

( ) $1 ;$ ( ) $2 ;$ ( ) 3

c. Are majority decisions necessary at different points in time?

( ) YES ( ) NO

\section{A GOOD SOURCE FOR MORE DETAILED INFORMATION IS}

(3) How are the members of the highest court elected/nominated? (PLEASE TICK THE APPROPRIATE LETTER)

a. Judges are nominated and elected by one or more members of the executive.

b. Judges are nominated by one or more members of the executive and are elected by parliament (or a committee thereof).

c. Judges are nominated by one or more members of the executive and are elected by the judiciary.

d. Judges are nominated and elected by parliament (or a committee thereof).

e. Judges are nominated by parliament (or a committee thereof) and are elected by one or more members of the executive.

f. Judges are nominated by parliament (or a committee thereof) and are elected by the judiciary.

g. Judges are nominated and elected by the judiciary. 
h. Judges are nominated by the judiciary and are elected by one or more members of the executive.

i. Judges are nominated by the judiciary and are elected by parliament (or a committee thereof).

j. Judges are nominated by the judiciary, the legislature, or the executive and are elected by actors not representing any government branch (academics, the public at large).

\section{A GOOD SOURCE FOR MORE DETAILED INFORMATION IS}

(4) What is the legal term length of the judges on the highest court?

NUMBER OF YEARS

In comparison, parliament's election period in number of years

\section{A GOOD SOURCE FOR MORE DETAILED INFORMATION IS}

(5) Can judges be reelected?

( ) YES ( ) NO

A GOOD SOURCE FOR MORE DETAILED INFORMATION IS

(6) How can judges be removed from office? (PLEASE TICK THE APPROPRIATE LETTER)

a. only by judicial procedure;

b. by decision of one or more members of the executive;

c. by decision of parliament (or a committee thereof);

d. by joint decision of one or more members of the executive and of parliament (or a committee thereof).

\section{A GOOD SOURCE FOR MORE DETAILED INFORMATION IS}

(7) Is there a measure against income reduction of judges? Is there a mechanism securing adjustment in real terms?

( ) YES ( ) NO 
(8) Are the judges paid adequately?

a. Are they paid more than university professors?

( ) YES ( ) NO

b. Are they paid more than an average private lawyer?

( ) YES ( ) NO

c. Are they paid as well as the minister of justice?

( ) YES ( ) NO

A GOOD SOURCE FOR MORE DETAILED INFORMATION IS

(9) Who has the possibility to access the highest court?

a. Individuals in any case relevant to the constitution and with which they are personally concerned.

b. Individuals, but only in a subset of cases relevant to the constitution (such as human rights).

c. Only other government branches.

A GOOD SOURCE FOR MORE DETAILED INFORMATION IS

(10) Is there a general rule allocating the responsibility concerning incoming cases to specific judges?

( ) YES ( ) NO

(or does the chief justice have discretion on the allocation of cases?) ( ) YES ( ) NO

A GOOD SOURCE FOR MORE DETAILED INFORMATION IS

(11) Does the constitution (or the law establishing the highest court) preview the power of constitutional review?

( ) YES ( ) NO

Are there any

limits

to

it

(e.g., only before a law has been promulgated?)

( ) YES ( ) NO

A GOOD SOURCE FOR MORE DETAILED INFORMATION IS

(12) Does the highest court have to publish

(a) the main reasons for a decision

( ) YES ( ) NO 
(b) an extended proof?

( ) YES ( ) NO

(12) Are dissenting opinions published regularly?

( ) YES ( ) NO

\section{A de facto measure for court independence}

(13) What has been the effective average term length of judges since the respective legal foundations have been passed? IN NUMBER OF YEARS

a. Does it deviate from the average term length to be expected by the legal foundations?

( ) YES ( ) NO

b. How many judges have been removed from office before end of term? NUMBER

A GOOD SOURCE FOR MORE DETAILED INFORMATION IS

(14) How many times has the number of judges been changed since 1970? NUMBER

A GOOD SOURCE FOR MORE DETAILED INFORMATION IS

(15) Has the income of judges remained at least constant in real terms since 1970 ?

( ) YES ( ) NO

A GOOD SOURCE FOR MORE DETAILED INFORMATION IS

(16) Has the budget of the highest court remained at least constant in real terms since 1970 ?

( ) YES ( ) NO

A GOOD SOURCE FOR MORE DETAILED INFORMATION IS

(17) How often have the relevant articles of the constitution (or the law on which the highest court is based) been changed since 1970 ?

NUMBER OF CHANGES

A GOOD SOURCE FOR MORE DETAILED INFORMATION IS 
(18) In how many cases has one of the other government branches remained inactive when its action was necessary for a decision to become effective between 2000 and 2009? NUMBER OF CASES

A GOOD SOURCE FOR MORE DETAILED INFORMATION IS

General comments (please feel free to make any comment): 